\title{
TOURISM AS A FACTOR OF REGIONAL DEVELOPMENT - TURIZEM KOT DEJAVNIK REGIONALNEGA RAZVOJA
}

Turizem je v današnjem svetu ena najhitreje rastočih gospodarskih dejavnosti. Zaradi koristi, ki jih prinaša, se ga pogosto ponuja kot rešitev za raznovrstne razvojne probleme na različnih prostorskih ravneh, spremljajočim negativnim učinkom navkljub. Na različne obraze turizma kot dejavnika regionalnega razvoja je opozoril tudi odmeven mednarodni simpozij, ki je 9. in 10. maja 2005 potekal v Tuzli, v organizaciji Oddelka za geografijo tamkajšnje Naravoslovno-matematične fakultete. Na simpoziju je sodelovalo okrog 50 udeležencev iz sedmih držav (Avstrija, Madžarska, Slovenija, Hrvaška, Bosna in Hercegovina, Makedonija ter Srbija in Črna gora), kar 26 pa jih je svoje poglede na obravnavano problematiko predstavilo z referati. Pohvalimo se lahko tudi s posebno močno udeležbo slovenskih geografov; kar petih sodelavcev Oddelka za geografijo v Ljubljani (D. Plut, A. Černe, D. Cigale, K. Vrtačnik in K. Vintar Mally), dveh sodelavcev Oddelka za geografijo v Mariboru (L. Lorber in U. Horvat) ter predstavnika ERICo Velenje (E. Šterbenk).

Prvi dan in dopoldan drugega dne, ki sta bila namenjena predstavitvi referatov in diskusijam, sta bila kar prekratka za bolj poglobljeno obravnavo vseh izpostavljenih vidikov in živahno izmenjavo mnenj. Vsebinsko smo se lotevali predvsem:

- teoretičnih izhodišč, kot so razmerja med turizmom na eni strani ter geografijo, okoljskimi viri in trajnostno sonaravnim razvojem na drugi strani,

- obstoječih in napovedanih globalnih in regionalnih trendov v razvoju turističnih dejavnosti,

- vrednotenja turističnih potencialov na primeru posameznih območij ter vprašanj načrtovanja njihovega turističnega razvoja,

- pomena turizma $\mathrm{v}$ gospodarstvih posameznih držav in njegovi vlogi $\mathrm{v}$ regionalnem razvoju,

- pozitivnih in negativnih ekonomskih, socialnih, kulturnih, okoljskih in prostorskih učinkov turizma in z njim povezanih dejavnosti,

- obravnave posameznih vrst turizma, med katerimi je največ referentov izpostavilo študije primerov zdraviliškega turizma, ekoturizma in verskega turizma.

Kot je razvidno iz zgoraj izpostavljenih tem, je znanstveno srečanje prineslo kar nekaj novosti v turistično-geografski obravnavi trenutnih razvojnih trendov in dilem na globalni ravni pa vse do študija primerov na lokalni ravni. Dvodnevno druženje se je zaključilo s poldnevno ekskurzijo po Tuzli in njeni okolici, s poudarkom na spoznavanju glavnih razvojnih problemov območja in možnostih razvoja turizma v regiji. Rezultati srečanja in predstavljeni referati bodo objavljeni $\mathrm{v}$ posebnem zborniku.

$\mathrm{Na}$ koncu pa velja izreči še posebej toplo zahvalo za uspešno izvedeno srečanje in gostoljubnost požrtvovalnemu glavnemu organizatorju srečanja, dr. Rahmanu Nurkoviću z Oddelka za geografijo v Tuzli. Tudi v bodoče se veselimo plodnega strokovnega sodelovanja z bosanskimi geografi!

Katja Vintar Mally 